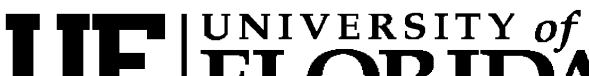 FLORIDA \\ IFAS Extension
}

FOR 172

\section{Urban Forest Educational Resources for Teaching Youth ${ }^{1}$}

\author{
Jennifer Seitz, Martha Monroe and Francisco Escobedo ${ }^{2}$
}

As Florida's population increases and cities continue to grow, the landscape will change. Small towns become big towns, in-fill development covers open lots, and sprawling suburbs expand into undeveloped areas. In most areas these changes mean that open lots with trees and forests disappear. However, in well-planned communities they can be accompanied by urban forests. Maybe you have already witnessed this phenomenon in your community. Why is this important to educators and outreach professionals?

The trees around our homes, schools, streets, and throughout our parks are part of an urban forest. The urban forest is made up of trees and other vegetation within the built environment where we live, work, and play. It is influenced by people, vehicles, pavement, utility lines, buildings, wildlife, underground pipes, other plants, and of course, people. An urban forest is an important community resource, providing many social, economical, and environmental benefits. It can help mitigate the negative effects of urban development by improving water quality, reducing air pollution, decreasing soil erosion, buffering noise pollution, and lessening the urban heat island effect. Green views and access to green spaces in urban areas can help lessen the everyday pressures of crowding, noise, and stress.
Urban trees provide economic savings such as reduced expenses for residential and commercial heating and cooling and funds needed to improve water and air quality.

The urban forest in your community is an important teaching tool. You can demonstrate the competitive, interdependent, cyclic nature of living things in the environment by focusing on wildlife and their habitats; examine how soil compaction affects water flow and tree health; and create maps indicating the type of trees present at a location and the amount of canopy cover it provides. Students can use the scientific method to hypothesize the effect the urban forest might have on stormwater runoff, air particulates, and ground temperature.

The resources listed below provide further background knowledge on urban forests and hands-on, critical thinking activities to supplement existing curricula or programs. Classroom teachers, extension agents, home school parents, nature center staff, foresters, and others interested in helping youth explore their urban environment can benefit from these materials. They come from the School of Forest Resources and Conservation at the University of Florida, Institute of Food and Agricultural Sciences (UF/IFAS); Project Learning Tree ${ }^{\circledR}$; and the United

1. This is document FOR 172, one of a series of the School of Forest Resources and Conservation, Florida Cooperative Extension Services, Institute of Food and Agricultural Sciences, University of Florida. First published: January 2008. Please visit the EDIS website at http://edis.ifas.ufl.edu.

2. Jennifer Seitz, Extension Associate, Martha Monroe, Associate Professor and Francisco Escobedo, Assistant Professor, School of Forest Resources and Conservation, Florida Cooperative Extension Services, Institute of Food and Agricultural Sciences, University of Florida, Gainesville, FL 32611.

The Institute of Food and Agricultural Sciences (IFAS) is an Equal Opportunity Institution authorized to provide research, educational information and other services only to individuals and institutions that function with non-discrimination with respect to race, creed, color, religion, age, disability, sex, sexual orientation, marital status, national origin, political opinions or affiliations. U.S. Department of Agriculture, Cooperative Extension Service, University of Florida, IFAS, Florida A. \& M. University Cooperative Extension Program, and Boards of County Commissioners Cooperating. Millie Ferrer-Chancy, InterimDean 
States Department of Agriculture. Materials are divided by organization and include the appropriate grade levels and Web address for additional information. The majority of the resources can be downloaded from the Internet at no charge or can be obtained by attending a workshop. Materials are copyrighted by the respective publishing organizations, but permission is given to photocopy pages for educational uses.

\section{School of Forest Resources and Conservation, UF/IFAS}

\section{Urban Forests: A Supplement to Florida's Project Learning Tree (CIR 1457) (3-8 grade), http://edis.ifas.ufl.edu/FR164}

This companion guide to the Project Learning Tree (PLT) program (see below) helps youth see their community's urban forests as significant, valuable, and worth sustaining. It is based on three themes: urban forest ecology, benefits of an urban forest, and strategies for improving an urban forest. This booklet identifies 28 PLT activities that already work well in urban areas; 19 PLT activities that can be adapted to be more applicable to an urban space; 6 extensions to existing PLT activities; and 6 new activities. Each activity includes background information and correlations to the Florida Sunshine State Standards.

\section{Give Forests a Hand Youth and Leader Guide (3-12 grade)}

\section{Youth Guide (CIR 1269), http://edis.ifas.ufl.edu/FR117}

This is a community service learning program that engages groups of youth in explorations and action projects based on trees and forests. The Youth Guide is a project book describing a process of problem identification, the search for more information, prioritizing activities, selecting a project, planning that project, carrying out the action, and finally celebrating success. The booklet includes four surveys for different types of forests: school forests, community forests, neighborhood trees, and rural forests. Each survey guides youth toward potential questions, concerns, and opportunities for action projects. Reflection questions at each step of the process help youth think about the skills they are building and the information they are learning. This resource helps create an educational program out of community projects like tree plantings, urban forest inventory, insect or disease monitoring, and outreach activities to raise public awareness. A Spanish version is also available (http://edis.ifas.ufl.edu/pdffiles/FR/FR14000.pdf).

Leader Guide (CIR 1270), http://edis.ifas.ufl.edu/FR118

The Leader Guide accompanies the Youth Guide with background and facilitation advice for adult leaders and teachers so they can help youth identify, plan, and conduct an action project. In addition to background on each step, it includes an activity bank and a list of resources that can assist in undertaking an action project. Reflection questions at each step help leaders contemplate what is working and what could be changed to facilitate the process. A Spanish version is also available (http://edis.ifas.ufl.edu/pdffiles/FR/FR14100.pdf).

\section{H Forest Project Books (K-12 grade)}

\section{Forest Resources Leader Guide (4H FOL 10), http://edis.ifas.ufl.edu/4H095}

This 64-page Leader Guide to the three Florida 4-H Forest Resources Project Books - Adopt a Tree, Trees and Me, and Florida's Fabulous Forests, provides background information, suggested responses for the discussion questions, and tips on how to assist youth with each activity. Correlations to PLT activities and answers to questions in the three project books are provided.

\section{Adopt a Tree (4HFOM11), http://edis.ifas.ufl.edu/FR121}

This project book engages children ages 5-8 in an exploration of Florida trees and forests. Youth locate and "adopt" a nearby tree, observe changes to the tree over time, do bark and leaf rubbings, and search for visiting wildlife. Youngsters are also introduced to three common and special Florida trees: cabbage palm, live oak, and longleaf pine. 


\section{Trees and Me (4HFOM12),} http://edis.ifas.ufl.edu/FR122

This publication for children ages 9-11, encourages a closer examination of trees. Youth learn basic tree physiology, identify 18 common Florida trees in our eight forest ecosystems, and focus on the many benefits and values of trees, from wooden houses and carpet, to restful and pleasing outdoor spaces.

\section{Florida's Fabulous Forests (4HFOM13), http://edis.ifas.ufl.edu/FR123}

The project book is designed for youth ages 12-18. Activities lead youth to explore 10 different kinds of forests in Florida; understand forest management issues such as prescribed fire, invasive exotics, and forest diseases; and examine forest systems (wildlife, water, and soil).

\section{Project Learning Tree}

Project Learning Tree (PLT) is a program of the American Forest Foundation. (http://www.plt.org). It has two resources, described below, that are relevant to urban forests. Materials are available in Florida through the School of Forest Resources and Conservation (http://sfrc.ufl.edu/plt).

\section{Environmental Education Activity Guide (PreK-8 grade)}

PLT uses trees and forests as the context to help young people gain an awareness and knowledge of natural and built environments. The manual contains 96 multidisciplinary activities grouped by theme, storyline, and subject matter. The majority of the activities emphasize readings, technology enhancements, authentic assessment, and differentiated instruction. Correlated to the Florida Sunshine State Standards, a variety of topics allow for integration into multiple lesson plans and programs.

\section{Exploring Environmental Issues: Places We Live Module (9-12 grade)}

This guide provides secondary educators with a useful tool for place-based education to help create a bond between young citizens and their communities. Students will explore current and future community environmental issues such as growth management and green infrastructure, enabling them to make informed decisions about those issues. The eight activities include case studies, instructions, and technology enhancements.

\section{United States Department of Agriculture (USDA)}

\section{Natural Inquirer (6-8 grade), http://www.naturalinquirer.usda.gov/}

Scientists from the USDA Forest Service share their research with middle school students in this science-based education journal. All of the research in each issue is concerned with trees, wildlife, insects, outdoor activities, or water. Students "meet the scientists" who conduct the research, read about a specific research project, and also read an article connecting science and the environment based on that issue's theme. A "Discovery FACTivity" follows each research project to provide students the chance to complete a survey, project, or answer questions about a similar scenario. Each journal is dedicated to a particular topic. Editions to date cover urban forests, invasive species, wildland fire, wilderness benefits, and renewable resources. Some issues are available in Spanish.

\section{Urban Forestry Laboratory Exercises (K-12 grade) \\ http://www.na.fs.fed.us/spfo/pubs/uf/ lab_exercises/cover.htm}

This guide features hands-on, data-gathering exercises that lead students to make judgments based on analysis and synthesis of their data. Each activity builds upon the previous one to reinforce a set of grade-specific skills. The guide has five areas of activity: tree identification and inventory, characteristics of trees, soil conditions for trees, condition of trees, and tree care and planting.

\section{Guest Speakers}

The addition of a presenter to your lesson or program can greatly enhance students' learning experiences. Presenters may be able to bring technology and tools of their profession or highlight potential career options for students. This is a great 
opportunity to bring in someone whose experience will complement your own. Below are organizations who offer staff for school and community presentations. There are probably other members in your community willing to share their expertise.

Florida Chapter of the International Society of Arboriculture

The International Society of Arboriculture provides a free Web search page to find a certified arborist near your community. Your local parks and recreation department may also have someone who can speak about maintaining a healthy urban forest. http://www.isa-arbor.com/findArborist/ findarborist.aspx

\section{Cooperative Extension Service}

Look in the blue pages of a phone book under County, Cooperative Extension Service for your local county office or visit the website. http://solutionsforyourlife.ufl.edu/map/index.html

\section{$\underline{\text { Florida Division of Forestry }}$}

County foresters are excellent resource people. Look in the blue pages of a phone book under State, Agriculture and Consumer Services Department, Forestry or visit their website. http://www.fl-dof.com/field_operations/ county_foresters/index.html

\section{Florida Society of American Foresters}

Contact Florida Project Learning Tree Central at (352) 846-2329 for scheduling a member of this organization to present.

\section{Master Gardeners}

Trained individuals participate in community and school garden projects, give educational programs to the public, and support youth activities. http://gardeningsolutions.ifas.ufl.edu/mastergardener/

\section{$\underline{\text { Master Naturalists }}$}

Individuals receive training in at least one subject area: freshwater wetlands, coastal systems, or upland habitats. http://www.masternaturalist.ifas.ufl.edu/

\section{Conclusion}

These resources can assist educators, extension agents, home school parents, foresters, and nature center staff as they help youth become more aware of the urban forests in their backyard.

\section{Suggested Readings}

Athman, J. and M.C. Monroe. 2002. Enhancing Natural Resource Programs with Field Trips (FOR 105). Gainesville FL: School of Forest Resources and Conservation, Florida Cooperative Extension Service, Institute of Food and Agricultural Sciences, University of Florida.

Eastman, J. and M.C. Monroe. 2001. Enhancing Natural Resources Programs with Service Learning (FOR 88). Gainesville FL: School of Forest Resources and Conservation, Florida Cooperative Extension Service, Institute of Food and Agricultural Sciences, University of Florida.

Fazio, J.R. 2003. Urban and Community Forestry: A Practical Guide to Sustainability. Lincoln NE: The National Arbor Day Foundation.

Fazio, J.R. Ed. 1998. The Way Trees Work-How to Help. Bulletin No. 38. Lincoln NE: The National Arbor Day Foundation.

Fazio, J.R. Ed. 1998. Working with Children. Bulletin No. 42. Lincoln NE: The National Arbor Day Foundation.

Monroe, M.C. 2006. Kids in the Woods (FOR 66). Gainesville FL: School of Forest Resources and Conservation, Florida Cooperative Extension Service, Institute of Food and Agricultural Sciences, University of Florida.

Monroe, M.C. 2001. Just Say YES to Youth Environmental Stewardship (FOR 89). Gainesville FL: School of Forest Resources and Conservation, Florida Cooperative Extension Service, Institute of Food and Agricultural Sciences, University of Florida.

Monroe, M.C., J. Randall, and V. Crisp. 2001. Improving Student Achievement with Environmental Education (FOR 87). Gainesville FL: School of 
Forest Resources and Conservation, Florida

Cooperative Extension Service, Institute of Food and

Agricultural Sciences, University of Florida.

Monroe, M.C., J. Seitz, S. Agrawal, M.

Aldridge, S. Morshed, E. Swiman, and V. Crisp.

2005. Improving Inservice Teacher Workshops in

Florida (FOR 109). Gainesville FL: School of Forest

Resources and Conservation, Florida Cooperative

Extension Service, Institute of Food and Agricultural

Sciences, University of Florida. 